\title{
Theresian Flags at the Croatian History Museum and their Iconographic Symbolism
}

Flags from Maria Theresa's era had regulated guidelines that had to be obeyed in order to produce the most representative as well as the most typical baroque banners. The ongoing military reforms launched by Maria Theresa, in conjunction with state-governing reorganizations, are also mirrored in the Collection of Flags and Streamers at the Croatian History Museum. In particular, there are four main representative flags that, on the one hand, show the practice of exhibiting statehood statuses by means of dynastic symbols on battalion standards, and on the other indicate the iconographic significance of saints and beatified kings on ceremonial and commemorative banners. These instructions were all done under the impression of the baroque style, the Age of Enlightenment, and the turbulent time of conflict in Maria Theresa's reign.

Keywords: Maria Theresa, Francis I, Frederick the Great, Age of Enlightenment, iconography, heraldry, vexillology, Order of the Golden Fleece, coat of arms, flags

Military reforms initiated by Maria Theresa altered the whole state-governing structure. These changes consequently affected the way in which art was made. The baroque style infused all artistic styles and even the way official flags were made. That particular innovation can be traced as well as researched on the Theresian flags in the collection of the Croatian History Museum. Painting of iconographic images was introduced out of financial and time constraints around 1766. ${ }^{1}$ Before the coronation of Francis I Stephen as the emperor of the Holy Roman Empire, flags briefly lost their familiar imperial colours used by the battalions, mainly the yellow and the black. In 1743, the regulative was that the flag

Mislav Barić, Croatian History Museum, Matoševa 9, 10000 Zagreb, Croatia, E-mail: m.baric@ hismus.hr

1 Jelena Borošak-Marijanović, Zastave kroz stoljeća [Flags through the centuries] (Zagreb: Croatian History Museum, 1996), 68-70. 
fields ought to be green or red with green-white-red border colours. The Leibfahne (regimental standard) sustained its white field with the image of the Virgin Mary on the one side and the imperial eagle on the other. It was not until 1745, when Francis I Stephen was crowned emperor of the Holy Roman Empire in Frankfurt, that the imperial colours (yellow and black) were reintroduced on official flags. ${ }^{2}$ Until 1766, the regulations introduced in 1745 mainly concerned the iconographic symbols. They legally defined the design of various baroque works of art that were to represent the current ruling house of the empire. The heraldic symbols of regions, cities, and states under the jurisdiction of a particular noble house were represented on its official military flags, such as the Battalion Flag of the Infantry Regiment, which will be discussed thoroughly in the following paragraphs. ${ }^{3}$

As a ruler, Maria Theresa does not fall into the category of the secular rulers of enlightened absolutism. ${ }^{4}$ Regulations that she introduced were heavily influenced by her advisors, such as her son and later coregent Joseph II, as well as van Swieten, Sonnenfels, and Bartenstein. They were the main proponents of the new reforms of the Enlightenment era. ${ }^{5}$ Wenzel Anton von Kaunitz in particular had a very clear vision of reforming the military balance of power in Europe along with reorganizing the whole Habsburg army. ${ }^{6}$ The later reforms of her son, known as "Josephinism," were under a heavy influence of Maria Theresa's legislative changes.7 Tax reforms were launched under the guidance and input of Frierdich Wilhgel von Haugwitz, and in 1760 continued under Kaunitz. These reforms were also connected to the military reforms such as the founding of the Theresian Military Academy in Wiener Neustadt. With the tax reforms being correlated to the military reforms, the army started to be transformed into a self-sustained standing army. ${ }^{8}$

2 Franz Gall, "Die ungarischen Truppen der Kaiserin Maria Theresia", in: Maria Theresia als König von Ungarn, ed. Gerda Mraz and Gerald Schlag (Eisenstadt: Amt der Burgenländischen Landesregierung, 1980), 42-43; Oscar Teuber, Die österreichische Armee 1700 bis 1867 (Vienna: Verlag von Emil Berte \& C. und S. Czeiger, 1897), 85.

3 Borošak-Marijanović, Zastave, 40.

4 Ferdo Šišić, Pregled povijesti hrvatskog naroda [Overview of the history of the Croatian people] (Zagreb: Matica Hrvatska, 1962), 329.

5 Martin Mutschaler, “The Dark Side of Maria Theresa”, http://www.habsburger.net/en/chapter/ dark-side-maria-theresa (last accessed on November 21, 2017).

6 Franz A. J. Szabo, Kaunitz and Enlightened Absolutism 1753-1780 (Cambridge: Cambridge Unversity Press, 1994), 258.

7 Karl Vocelka, "Der 'Josephinismus' in der Maria Theresianischen Epoche”, in: Österreich zur Zeit Kaiser Josephs II., ed. Karl Gutkas, Gottfried Stangler, Elisabeth Schmuttermeier and Sylvia Wurm (Vienna: Stift Melk, 1980), 152.

8 Elfried Iby, Monica Kurzel-Runtscheiner, Werner Telesko, Karl Vocelka, "Maria Theresia, Strategin-Mutter-Reformerin, Biografische Eckdaten”, in: Maria Theresia als König von Ungarn, ed. Gerda Mraz and Gerald Schlag (Eisenstadt: Amt der Burgenländischen Landesregierung, 1980), 30. 
"Maria Theresia ist wahrhaftig ein mater castrorum, eine Heeresmutter, geworden, ebenso wie sie eine wahre Landesmutter war." - Oscar Teuber, Die österreichische Armee 1700 bis 1867, Vienna, 1897, 79.

As Teuber stated, the perception of Maria Theresa as an adept ruler stems from her comprehensive reforms of state and military governance. Therefore, attributes such as mater castrorum, Heeresmutter, or Landesmutter remained the norm long after her death.

Reforming and improving the educational system was also one of the concerns Maria Theresa regulated and wanted to improve. Schools at the Croatian Military Frontier were to be rebuilt and the exact cost estimate for the renovation works was demanded in $1775 .{ }^{9}$

Likewise, as a queen she attached great importance to the religion of the monarchy, including the religious symbols on official flags. A flag, be it a Leibfahne or a Regimenterfahne, featured religious and secular symbols that demonstrated the dual power as it was defined by the philosophers of the Enlightenment. ${ }^{10}$ It was represented by engraved images of saints on the finials or by an image of the Virgin Mary directly on the flag. The baroque style influenced flag decorations and also expressed the spirit of the time and the tendency to represent the imperial reign in terms of wondrousness. ${ }^{11}$ The appearance of flags was further regulated in 1754, when the usage of dynastic symbols was proclaimed mandatory and the size and decorations were precisely determined. ${ }^{12}$

The Battalion Flag of the Infantry Regiment in the Collection of Flags and Streamers at the Croatian History Museum was made between 1745 and 1765 and is decorated with the dynastic symbols of the Habsburgs. Secular symbolism is represented by a black double-headed eagle, while St Charles Borromeo, engraved on the flag finial, is used as a religious symbol..$^{13}$ Both iconographic images represent not only the baroque style of the time, but also the political sentiment of Maria Theresa. As a secular ruler, she defined the use of the crowned, dynastic, double-headed eagle with a shield on its chest. This particular battal-

\footnotetext{
9 Walter Wagner, “Ausstelungskatalog”, in: Maria Theresia als König von Ungarn, ed. Gerda Mraz and Gerald Schlag (Eisenstadt: Amt der Burgenländischen Landesregierung, 1980), 174.

${ }_{10}$ Certain regulations that she authorized deviate from the spirit of the Enlightenment, such as the continued physical punishment of soldiers, especially deserters, and the confiscation of their property. The Criminalis Constitutio Theresiana (1769) gives instructions on the torture and physical punishment felons (CRO - CHM - DC I - MRRP - HPM/PMH-24298; Vocelka, "Aufbruch", 44).

11 Borošak-Marijanović, Zastave, 68-92.

12 Željko Heimer, "Identitet Oružanih snaga Republike Hrvatske iskazan zastavama vojnih postrojbi u Domovinskom ratu i nakon njega" [Identity of the armed forces of the Republic of Croatia, expressed through the flags of regiments during the Croatian Liberation War and afterwards] (PhD diss. University of Zagreb, 2013), 139.
}

13 Borošak-Marijanović, Zastave, 120. 
ion flag falls into the category of Regimenterfahne. ${ }^{14}$ The field of those flags is typically yellow, the bordures are decorated with black-white-red-yellow flickers, and both the obverse and the reverse are decorated in the same fashion. On the reverse, there is a black double-headed eagle with a shield on its chest featuring the coats of arms of Hungary, Bohemia and Austria, joint together to portray Maria Theresa's rule over those provinces. The black, crowned, double-headed eagle is situated on the obverse side of the flag as well, and also carries a shield on its chest, but this time with the coats of arms of Tuscany and Lorraine, which represent her husband Francis I Stephen. Encircling the shield, there is the collar of the Order of the Golden Fleece, since Francis I was its Grand Master. As Francis I Stephen was crowned emperor of the Holy Roman Empire in 1745, the prominent yellow and black colours, and the double-headed eagle, could be used once again, the latter holding a sceptre and a sword in its claws to symbolize the military and imperial character of the flag..$^{15}$ On the other hand, the engraved image of St Charles Borromeo on the finial symbolizes Maria Theresa's attitude towards the Protestant Reformation, since Borromeo was an important figure of the Counterreformation and his cult was spread throughout the Habsburg lands. ${ }^{16}$ Since this battalion flag was also a military one, the finial bears the coat of arms of the Batthyány family on the reverse, since they were the landowners at the time in Croatia and Hungary. Their heraldic blazon consists of a pelican in its nest atop a rocky mountain, with a cave underneath and a lion protruding from it, holding a sword in its mouth. This image also has an engraved crown above it, and around the edges there is the chain of the Order of the Golden Fleece, as the Batthyány family were its prominent members. The lion is a typical heraldic symbol of military prowess, which is why the Batthyány family is represented by a lion holding a sword, as well as an axe within a bundle engraved in this coat of arms. An entire range of socio-political and religious sentiments of rulers can be read and interpreted from the symbols used in this flag. The two persons that make up the fabric of the ruling dynasty in the Habsburg Monarchy have their own crests on either side of the flag. ${ }^{17}$

The practice of having flags with both secular and religious symbols can also be seen on the two flags of the Zagreb Chapter (Kaptol) from Maria Theresa's time. Both flags are one-sided and therefore have the same image on the obverse and reverse sides. One flag and its finial show an image of St Ladislaus. One side of the

\footnotetext{
14 Heimer, “Identitet Oružanih snaga," 139-140.

15 Borošak-Marijanović, Zastave, 120.

16 Anđelko Badurina, ed., Leksikon ikonografije, liturgike i simbolike zapadnog kršćanstva [Lexicon of the iconography, liturgy, and symbolism of Western Christianity] (Zagreb: Kršćanska sadašnjost, 2000), 351; Jochen Boberg, Sabine Kimpel, Gregor Martin Lechner, Liesolotte Schütz, Friederike Tschochner, ed., Lexikon der christlichen Ikonographie, Bd. 7 (Rome; Freiburg; Basel; Vienna: Herder, 1990), 274-275.
}

17 Borošak-Marijanović, Zastave, 120. 
finial has the Latin inscription "FRANCISO I. MARIAE THERESIAE AVGVSTIS ET POSTERITATI / S LADISLAVS RH" and the other side the crest of Francis Thauszy with the inscription "LAETIUS IN EPISCOPIO ZAGREBIENSI AVGVSTA PRAESENTIA CROATIAE POPVLIS FRANCISCVS THAVSZY BONIT."18 Again, both symbols of the secular and sacral rulers are featured so as to emphasize the divine and the earthly authority. Saint Ladislaus as a knight-ruler is used as an example of knighthood and chivalry, while Francis Thauszy was the bishop of Zagreb at the time. ${ }^{19}$ This flag also has its own streamer with the inscription "ZA BOGA Y VERU / ZA KRALYA Y DOMOVINU" ("For God and Faith / For the King and the Homeland"). The tendency to combine secular and sacral elements is manifest in this inscription. ${ }^{20}$ Saint Ladislas could also be connected to Francis Stephen as the coregent, and moreover, Ladislas is credited with having founded the Zagreb bishopric.

The second flag of the Zagreb Chapter, which was made at the same time, is also one-sided but has a different iconographic image. The Virgin Mary of the Immaculate Conception stands on a cloud and a snake holding an apple in its mouth. The finial has the same Latin text as the aforementioned flag of the Zagreb Chapter, but with an image of the Virgin Mary of the Immaculate Conception engraved on the one side, and the same coat of arms of Francis Thauszy on the other. ${ }^{21}$ Maria Theresa was also considered as a protégé of the Mother of God. This connection was supported by the widespread Marian cult in the $18^{\text {th }}$ century, ${ }^{22}$ as well as the fact that both flags were to be handed to Maria Theresa and Francis I during their supposed visit in Zagreb, that was to take place around $1754 / 1755 .{ }^{23}$ Presumably, the flag with the image of the Virgin Mary was to be presented to Maria Theresa on that occasion, while the flag one with the image of St Ladislas was intended for Francis I. ${ }^{24}$ However, Maria Theresa's and Francis I Stephen's visit to Zagreb never materialized despite the extensive preparations for their ceremonial reception. ${ }^{25}$ The reason given by Krčelić in his book Annuae was the danger posed by the bad roads and uprisings as well as by the urging of the Hofrat to steer the focus on to Frederic the Great in the looming Seven Years War. ${ }^{26}$

\footnotetext{
18 Borošak-Marijanović, Zastave, 97.

19 Borošak-Marijanović, Zastave, 97; Badurina, Leksikon ikonografije, 401.

20 Borošak-Marijanović, Zastave, 97.

21 Borošak-Marijanović, Zastave, 99.

22 Anna Coreth, Pietas Austriaca - Österreichusche Frömmigkeit im Barock (Munich: R. Oldenbourg Verlag, 1982), 45-50.

${ }_{23}$ Baltazar Adam Krčelić, Annuae sive Historia (Zagreb: Academia Scientiarum et atrium slavorum meridionalium, 1952), 245.

24 Borošak-Marijanović, Zastave, 97-99.

25 Krčelić, Annuae, 134-141.

26 Krčelić, Annuae, 245.
} 
The Croatian History Museum also possesses other types of flags from Maria Theresa's time that display the whole range of baroque art and the artistry of flag making. One such example is the flag of the Hussar Squadron of Karlovac. A typical cavalry flag, it is made out of yellow damask and decked with embroidered decorations and fringes around the edges. The obverse shows the coat of arms of Maria Theresa composed of the coats of arms of Hungary and Bohemia, and set next to the coat of arms of Francis I with the coats of arms of Lorraine and Tuscany. The imperial double-headed eagle holds the sword and the orb, which can be interpreted as the symbols of earthly and heavenly authority. The reverse is interesting in particular because it bears images of military trophies from the Roman Empire era. The shields have the Latin inscription "ILLYRICA COHORS / HERCULIANI / IOVIANI". The inscriptions symbolize the Roman Legio V "Iovia" and Legio VI "Herculia," which were stationed in the province of Illyricum and served as the personal guard of Emperor Diocletian and his co-emperor Maximian. The Hussar Squadron of Karlovac was formed in 1746 and disbanded in 1780. Because of its place of origin, the town of Karlovac, which is situated in the ancient province of Illyricum, the symbolism of images reaches back to the Roman times. The Karlovac regiment consisted of four squadrons commanded by Martin von Knežević and participated in the Seven Years' War. ${ }^{27}$

The finial of the flag of Francis Trenck bears the image of St Joseph carrying Jesus on one arm and a flowering rod in his other hand. He is shown sitting on a cloud with the inscription "PRO DEO REGE ET PATRIA" underneath. St Joseph is the symbol of the Church, but also the protector of the sick and the bearer of good death; thus he could be chosen as the patron and protector of Trenck's battalion. ${ }^{28}$ The other side of the finial shows the coat of arms of the Trenck family, consisting of quartered fields alternately decorated with bull heads between two stars and laurel wreaths. Above the shield, there are two plumed helmets and two unicorn supporters. Underneath there are drums, canons, and spears. The coat of arms is decorated with typical military insignia such as helmets and weapons. The Latin inscription underneath St Joseph expresses the spirit of the time by praising the monarchy and God at the same time. Francis Trenck served 18 years in the Infantry Regiment "Nikolaus Pálffy." He left military service two times before 1741, when he trained 1000 Pandurs for Maria Theresa. His exceptional discipline and the effectiveness of his Pandurs became renowned as well as infamous for the violent and marauding behaviour of his troops. Therefore Trenck was brought before the military court and sentenced to house arrest in the Spielberg fortress. ${ }^{29}$

\footnotetext{
27 Borošak-Marijanović, Zastave, 120-121.

28 Badurina, Leksikon ikonografije, 336 and 623.

29 Gerda Mraz, "Ausstelungskatalog”, in: Maria Theresia als König von Ungarn, ed. Gerda Mraz and Gerald Schlag (Eisenstadt: Amt der Burgenländischen Landesregierung, 1980), 181.
} 
As all museum objects have their own stories, the Croatian History Museum has its very own, interesting one regarding the Theresian flags. A particular flag from the War of the Austrian Succession was stored at the Museum and was regarded as a Prussian flag of Frederick the Great. The flag was made of blue silk, which faded with time, and featured an eagle holding a sword and a bolt of lightning. Above it was the Latin inscription "PRO GLORIA ET PATRIA" and around the image there were flamelets symbolizing the presence of the Holy Spirit. Judging by its description, it was a typical Prussian flag, but the Museum documentation states that it was taken by the Croatian soldiers from Fredrick the Great's tent during the Battle of Kolín in 1757. ${ }^{30}$ It was stored at the museum until World War II, when the Ustasha regime ordered it to be taken away. ${ }^{31}$ Ante Pavelić, the head of the Ustasha regime, took the flag and gave it as a personal present to Hitler along with a game of chess, also reported to formerly having belonged to Frederick the Great. Those items were presented to Hitler on their first meeting in Berghof in 1941, which was filmed and documented. ${ }^{32}$ This was the last information on the flag and the last occasion it was seen and recorded with a camera. ${ }^{33}$ The socio-political situation of the times is represented through symbols such as flags, streamers, and finials. By analysing these images, one can make conclusions about the rulers' religious sentiments and the constantly changing political climate of their times. Changes in the political situation influenced the regulations of flag making: the way in which images on flags were made and the symbols represented on the finials, which showed which family house was in charge of a particular battalion. Every particular museum object has its own unique story and those can be read and interpreted not only through the documentation available, but also from the symbolism of the items themselves and the images that they bear. Flags in particular are used to represent battalions, states, societies, and other institutions and therefore carry a message inside their motifs and images. Therefore, it is crucial to carefully interpret them in order to correctly unlock the unique information they contain.

\footnotetext{
30 Ela Jurdana, Statističko-topografski upitnici za područje Banske Hrvatske i Vojne krajine iz 1850. i 1858. godine [Statistical-topographic questionnaires for Banal Croatia and the Military Frontier (1850 and 1858] (Zagreb: Croatian History Museum, 2016), 19.

31 According to the available documentation at the Croatian History Museum.

32 Ante Pavelić, Doživljaji - kako sam osnovao Nezavisnu Državu Hrvatsku [Memoires: How I founded the Independent State of Croatia] (Zagreb: Despot Infinitus, 2015), 169.

33 Pavelić, Doživljaji, 162.
} 


\section{Archival sources}

Croatia - Croatian History Museum, Zagreb - Documentary Collection I - Military Rules and Regulations on Punishment - HPM/PMH-24298, article 13 (CRO - CHM - DC I - MRRP - HPM/PMH-24298).

\section{Published sources and literature}

Badurin, Anđelko, ed. Leksikon ikonografije liturgike i simbolike zapadnog kršćanstva. Zagreb: Kršćanska sadašnjost, 2000.

Boberg, Jochen; Kimpel, Sabine; Lechner, Gregor Martin; Schütz, Liesolotte; Tschochner, Friederike, ed. Lexikon der christlichen Ikonographie, Siepter Band. Rom; Freiburg; Basel; Wien: Herder, 1990.

Borošak-Marijanović, Jelena. Zastave kroz stoljeća. Zagreb: Hrvatski povijesni muzej, 1996.

Coreth, Anna. Pietas Austriaca - Österreichusche Frömmigkeit im Barock. München: R. Oldenbourg Verlag, 1982.

Gall, Franz. "Die ungarischen Truppen der Kaiserin Maria Theresia". In: Maria Theresia als König von Ungarn, ed. Gerda Mraz and Gerald Schlag, 38-44. Eisenstadt: Amt der Burgenländischen Landesregierung, 1980.

Heimer, Željko. "Identitet Oružanih snaga Republike Hrvatske iskazan zastavama vojnih postrojbi u Domovinskom ratu i nakon njega". Doctoral dissertation, University of Zagreb, 2013.

Iby, Elfried; Kurzel-Runtscheiner, Monica; Telesko, Werner; Vocelka, Karl, ed. "Maria Theresia, Strategin-Mutter-Reformerin, Biografische Eckdaten". In: $\mathrm{Ma}$ ria Theresia als König von Ungarn, ed. Gerda Mraz and Gerald Schlag, 28-43. Eisenstadt: Amt der Burgenländischen Landesregierung 1980.

Jurdana, Ela. Statističko-topografski upitnici za područje Banske Hrvatske i Vojne krajine iz 1850. i 1858. godine. Zagreb: Hrvatski povijesni muzej, 2016.

Krčelić, Bartol. Annuae sive Historia. Zagrabiae: Academia Scientiarum et atrium slavorum meridionalium, 1952.

Mutschaler, Martin. “The Dark Side of Maria Theresa”. http://www.habsburger. net/en/chapter/dark-side-maria-theresa, (last accessed on November 21, 2017).

Pavelić, Ante. Doživljaji - kako sam osnovao Nezavisnu Državu Hrvatsku. Zagreb: Despot Infinitus, 2015.

Szabo, Franz A. J. Kaunitz and Enlightened Absolutism 1753-1780. Cambridge: Cambridge University Press, 1994. 
Šišić, Ferdo. Pregled povijesti hrvatskog naroda. Zagreb: Matica hrvatska, 1962.

Teuber, Oscar. Die österreichische Armee 1700-1867. Wien: Verlag von Emil Berte \& Cie. und S. Czeiger, 1895.

Vocelka, Karl. "Aufbruch in neue Zeiten, Der Reformeifer Maria Theresias". In: Maria Theresia 1717-1780, Strategin, Mutter, Reformerin, ed. Elfriede Ilby, Martin Mutschlechern, Werner Telesko, Karl Vocelka, 44-56. Wien: Schloss Schönbrunn; Kunsthistorisches Museum Wien, 2017.

Vocleka, Karl. “Der „Josephinismus“ in der Maria Theresianischen Epoche”. In: Österreich zur Zeit Kaiser Josephs II., ed. Karl Gutkas, Gottfried Strangler, Elisabeth Schmuttermeier, Sylvia Wurm, 148-152. Wien: Stift Melk, 1980. 


\section{Mislav Barić *}

\section{Terezijanske zastave u Hrvatskom povijesnom muzeju i njihov ikonografski simbolizam}

\section{Sažetak}

Zastave iz doba Marije Terezije imale su regulirana pravila koja su se trebala poštivati kako bi se proizvela najreprezentativnija i tipična barokna zastava. Provođenje vojnih reformi Marije Terezije zajedno sa upravnim reorganizacijama može se također vidjeti u Zbirci zastava i zastavnih vrpca Hrvatskog povijesnog muzeja. Posebno su reprezentativne četiri zastave koje s jedne strane svjedoče o prikazivanju državno-pravnog statusa sa dinastičkim simbolima na bataljunskim zastavama, te s druge strane naznačuju ikonografsku važnost svetaca i beatificiranih kraljeva na ceremonijalnim i komemorativnim zastavama. Sve ove smjernice učinjene su pod utjecajem baroka, prosvjetiteljstva i turbulentnog vremena i sukoba za vrijeme vladanja Marije Terezije.

Ključne riječi: Marija Terezija, Franjo I., Fridrik Veliki, prosvjetiteljstvo, ikonografija, heraldika, veksilologija, Red zlatnog runa, grbovi, zastave 